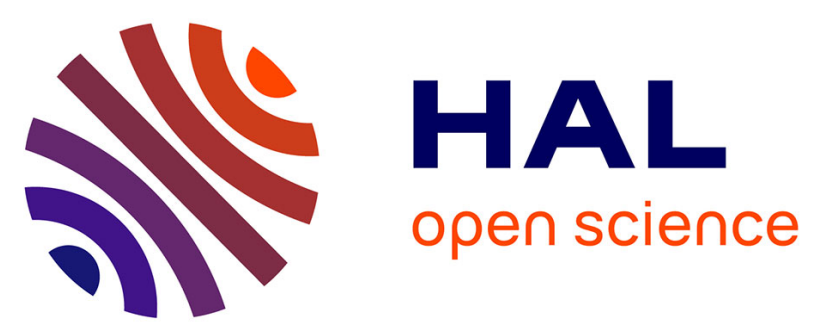

\title{
Convection at very high Rayleigh number: signature of transition from a micro-thermometer inside the flow
}

\author{
Julien Salort, Frédéric Gauthier, Benoît Chabaud, Olivier Bourgeois,
} Jean-Luc Garden, Ronald Du Puits, Andre Thess, Philippe-Emmanuel Roche

\section{- To cite this version:}

Julien Salort, Frédéric Gauthier, Benoît Chabaud, Olivier Bourgeois, Jean-Luc Garden, et al.. Convection at very high Rayleigh number: signature of transition from a micro-thermometer inside the flow. 12th EUROMECH European Turbulence Conference, Sep 2009, Marburg, Germany. pp.159-162, 10.1007/978-3-642-03085-7_40. hal-00430188

\section{HAL Id: hal-00430188 \\ https://hal.science/hal-00430188}

Submitted on 12 Aug 2010

HAL is a multi-disciplinary open access archive for the deposit and dissemination of scientific research documents, whether they are published or not. The documents may come from teaching and research institutions in France or abroad, or from public or private research centers.
L'archive ouverte pluridisciplinaire HAL, est destinée au dépôt et à la diffusion de documents scientifiques de niveau recherche, publiés ou non, émanant des établissements d'enseignement et de recherche français ou étrangers, des laboratoires publics ou privés. 


\title{
Convection at very high Rayleigh number: signature of transition from a micro-thermometer inside the flow
}

\author{
J. Salort ${ }^{1}$, F. Gauthier ${ }^{1}$, B. Chabaud ${ }^{1}$, O. Bourgeois ${ }^{1}$, J.-L. Garden ${ }^{1}$, R. du \\ Puits $^{2}$, A. Thess ${ }^{2}$ and P.-E. Roche ${ }^{1}$ \\ ${ }^{1}$ Institut Néel, CNRS / UJF, BP166, 38042 Grenoble CEDEx 9, France \\ 2 Department of Mechanical Engineering, Ilmenau University of Technology, P.O. \\ Box 100565, 98684 Ilmenau, Germany \\ julien.salort@grenoble.cnrs.fr
}

\section{Introduction}

In 2001, a change in the statistics of temperature fluctuations in RayleighBénard convection was reported at very high Rayleigh number $\left(\mathrm{Ra} \sim 10^{12}\right)[1]$. This change was concomitant with an enhancement of the heat transfer which had been interpreted [2] as the triggering of Kraichnan Convection Regime [3]. But a systematic study of finite probe size effect showed that the $200 \mu \mathrm{m}$ probe used in the 2001 study was about three times too large to be free from finite size correction [4], calling for a confirmation of these results. We report new measurements of temperature fluctuations performed with a probe ten times smaller than the one used in 2001.

In this proceeding, we discuss experimental aspects of this experiment and complementary measurements made in the "Barrel of Ilmenau". The first experiment was conducted with cryogenic helium and the second with air. Once combined, those two experiments lead to evidence of a signature of a transition in the local temperature fluctuations, supporting the conclusion of the 2001 study.

\section{Micron-size thermometer}

The temperature probe is a $17-\mu \mathrm{m}$ glass fiber, on which a $1 \mu \mathrm{m}$ layer of $\mathrm{NbN}$ [5] was deposited and annealed. The fiber and its stainless steel frame was glued on a wooden tripod. The fiber is placed two millimeters above the bottom plate of a 43-cm-high 10-cm diameter convection cell (see figure 1). It is connected to two pairs of copper wires for the 4-wire-measurement. We were careful not to over-heat the fiber with the measuring current to avoid hot-wire 


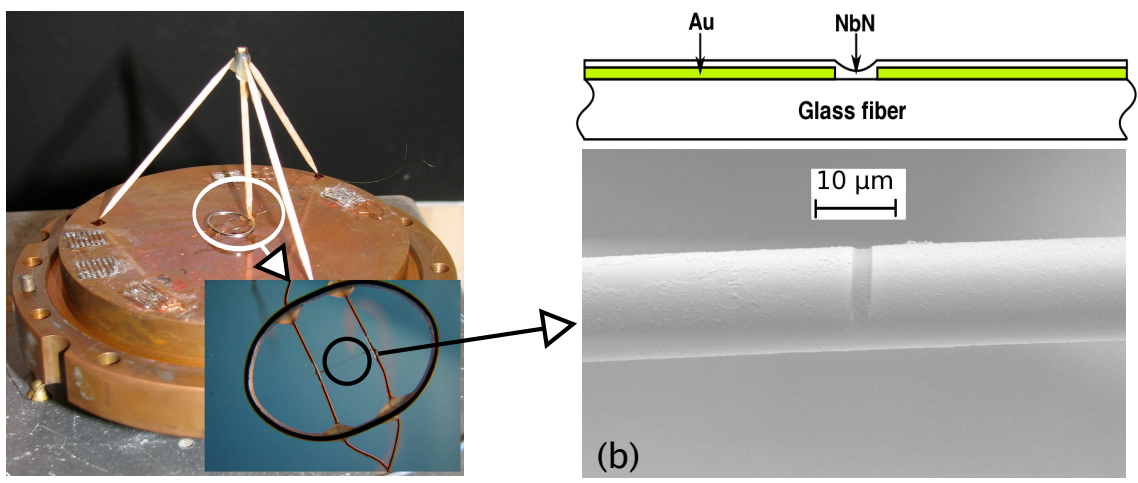

Fig. 1. (a) Temperature probe on its tripod above the bottom plate of the 43-cmhigh cryogenic Rayleigh-Bénard cell. Inset: detail on the web-like fiber support. (b) Drawing and electronic microscope picture of the sensitive element

artefact. As can be seen on figure 2, the fiber starts to self-heat meaningfully for input current of order of $1 \mu \mathrm{A}$. All subsequent measurements were done with an input current of $0.5 \mu \mathrm{A}$.

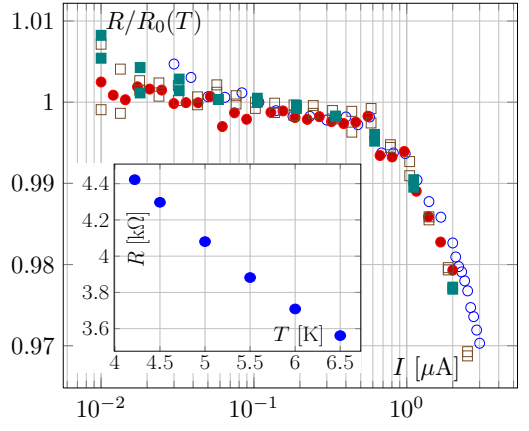

(a)

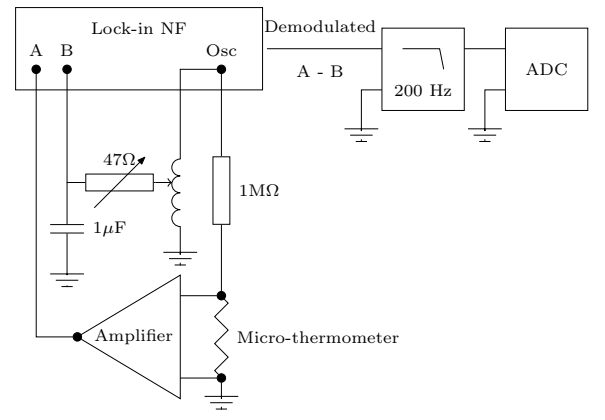

(b)

Fig. 2. (a) Self-heating of the micro-thermometer for various experimental conditions. $\rho=1.6 \mathrm{~kg} / \mathrm{m}^{3}, T \approx 6.5 \mathrm{~K}(\circ) ; \rho=6.5 \mathrm{~kg} / \mathrm{m}^{3}, T \approx 6.0 \mathrm{~K}(\bullet) ; \rho=19 \mathrm{~kg} / \mathrm{m}^{3}$, $T \approx 6.0 \mathrm{~K}(\square) ; \rho=40 \mathrm{~kg} / \mathrm{m}^{3}, T \approx 6.0 \mathrm{~K}(\mathbf{\square})$. Inset : Resistance of the fiber versus temperature. (b) Electronic diagram of the acquisition system.

The temperature response of the probe is calibrated versus Ge thermometers in homogeneous temperature conditions. We find a temperature sensitivity $\partial \ln R / \partial \ln T \simeq 0.7$ at $5 \mathrm{~K}$ (see inset in figure 2 ). The performance is limited by a resistance noise with spectral density $1.5 \times 10^{-6} / f$, where $f$ is the frequency in Hertz, corresponding to a rms noise of order $1 \mathrm{mK}$ over the bandwidth 
of interest. This noise prevented operation above $R a=5 \times 10^{13}$ in order to maintain Boussinesq conditions.

The fluctuation data was acquired using the electronic setup shown on figure $2:$ the input current is provided by the generator of a $N F$ Lock-In Amplifier LI-5640 $(V=500 \mathrm{mV}, f=7825 \mathrm{~Hz})$. The voltage drop across the fiber is pre-amplified (JFET, Gain $10^{4}$, typical noise input voltage $700 \mathrm{pV} / \sqrt{\mathrm{Hz}}$ ). We substract the mean-value of the temperature signal using a Singer inductor bridge and an adjustable $R C$ filter to compensate for the phase shift, in order to use all the dynamics of the Lock-in. The demodulated signal is filtered by a General Purpose Kemo 1208/20/41LP low-pass filter (8 pole Elliptic filter with a flat passband, frequency cutoff $200 \mathrm{~Hz}$ ) to avoid aliasing and then acquired by a NI Analog-Digital Converter NI6289 (18 bits).

\section{Results and interpretation}

Following Chavanne et al. [1], we consider the exponent $\xi_{2}$ of the $2^{\text {nd }}$ order structure function of the temperature fluctuations $T(t)$ :

$$
\xi_{2}=\frac{\mathrm{d} \log \left\langle(T(t+\tau)-T(t))^{2}\right\rangle_{t}}{\mathrm{~d} \log \tau}
$$

where the brackets represent time averaging. The dependence of $\xi_{2}$ versus the time increment $\tau$ holds the same information as a temperature spectrum.

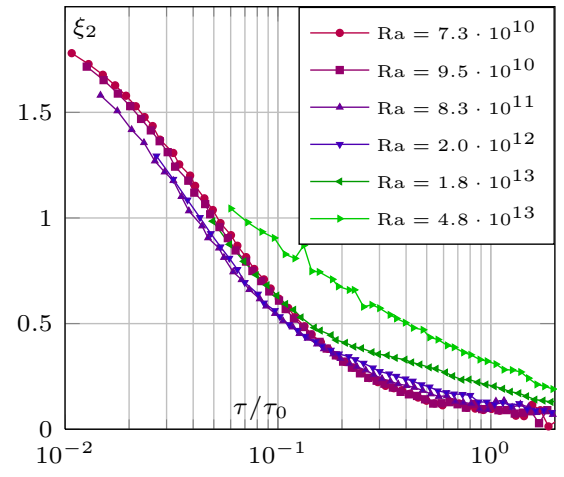

(a) Second-order increments.

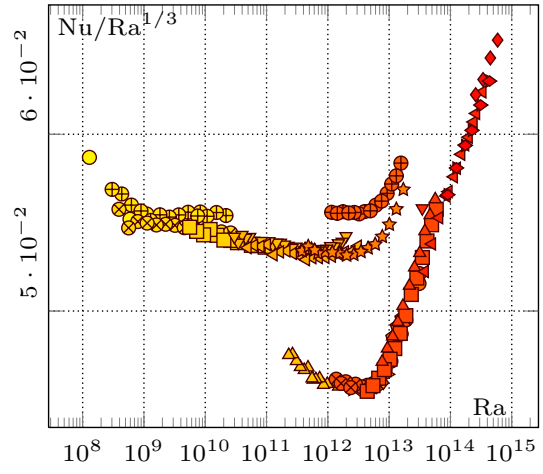

(b) Compensated heat-transfert data.

Fig. 3. Data measured in the 43-cm Rayleigh-Bénard cell.

Fig. 3-a shows $\xi_{2}$ versus the dimensionless increment $\tau / \tau_{0}$ where $\tau_{0}=$ $(h / 2 \mathrm{Nu})^{2} / \kappa$ is a caracteristic time scale of the flow. A change of shape occurs above $\mathrm{Ra} \approx 10^{13}$, which is also the threshold Ra for which a heat transfer transition is measured in this cell, as shown on fig. 3-b. The observed jumps of 
$N u(R a)$ are characteristic of the multiple possible configurations of the mean large scale circulation in elongated cells. They are known to hardly affect the temperature spectra, and therefore $\xi_{2}$, although they can be responsible for a few tens of $\%$ offset of the x-axis of fig.3-a through the $N u$ dependence of $\tau_{0}$.

For $\mathrm{Ra} \geq 10^{12}, h / 2 \mathrm{Nu} \leq 400 \mu \mathrm{m}<2 \mathrm{~mm}$ : the probe is clearly outside the thermal boundary layer. We also studied the systematic dependance of $\xi_{2}(\tau)$ versus the probe-plate distance below the transition $\left(\mathrm{Ra}=3.2 \times 10^{11}\right)$ in the "Barrel of Ilmenau" in the range $0.1<z /(h / 2 \mathrm{Nu})<20.3$. This study reported in [4] showed that the variation of this effective plate-probe distance cannot explain the transition observed on the temperature statistics.

The observed change in shape of $\xi_{2}$ is consistent with Chavanne et al.'s qualitative observations, confirming a posteriori that their observation was not an artefact although it was partly altered by a finite size effect [1].

\section{Conclusion}

The regime observed (and named "Ultimate Regime") in [1] is thus characterised by 3 specific signatures : an integral one (heat transfer enhancement) and localized ones on the thermal boundary layer [6] and inside the flow as shown in this paper (see also [4]). These signatures are compatible with Kraichnan's prediction [3] but more work is certainly needed to understand the basic mechanism of the flow instability at very high Ra.

Acknowledgements : We thank B. Hébral, F. Chillà and more especially B. Castaing for numerous discussions. The assistance of T. Fournier, P. Diribarne and P. Lachkar in instrumentation is gratefully acknowledged. A Procope collaboration was made possible thanks to Deutscher Akademischer Austauschdienst (D/0707571) and Ministère des Affaires Etrangères (17858YD)

\section{References}

1. Turbulent Rayleigh-Bénard convection in gaseous and liquid He, X. Chavanne et al., Phys. Fluids, 13:1300, 2001

2. Observation of the ultimate regime in Rayleigh-Bénard convection, X. Chavanne et al., Phys. Rev. Lett., 79:3648, 1997

3. Turbulent thermal convection at arbitrary Prandtl numbers, R. KRAICHnAN, Phys. Fluids, 5:1374, 1962

4. Temperature fluctuations in the Ultimate Regime of Convection, F. GauthiER et al., to be submitted in 2009

5. Liquid nitrogen to room-temperature thermometry using niobium nitride thin films, O. Bourgeois et al., Rev. Sci. Instruments, 77:126108, 2006

6. Evidence of a boundary layer instability at very high Rayleigh number, F. GAUTHIER and P.-E. ROCHE, EPL, 83:24005, 2008 